Prof. Benndorf, physicist, University of Graz. Prof. Felix Ehrenhaft, physicist, University of Graz. Prof. Fritz Feigl, analytical chemist, University of Vienna.

Prof. Fuerth, physiological chemist, University of Vienna.

Prof. Philipp Gross, physico-chemist, University of Vienna.

Prof. Victor Hess, physicist, University of Graz

(Nobel Prize winner).

Prof. Mark, physico-chemist, University of Vienna.

Prof. Stephan Meyer, director of the Radium

Institute of the Academy of Sciences, Vienna.

Prof. Pauli, colloidal chemist, University of Vienna.

Prof.Karl Przibram, physicist, University of Vienna.

Prof. Hans Thirring, theoretical physicist, University of Vienna.

Prof. Otto Redlich, physico-chemist, Technical High School of Vienna.

Among the arrested are :

Prof. Baule, mathematician, University of Graz.

Prof. Karl Buehler, psychologist, University of Vienna (since released).

Prof. Dobretsberger, rector of the University of Graz.

Prof. Loewi, physiological chemist and pharmacologist, University of Graz (Nobel prize winner).

The following professors have been dismissed from the famous medical school of Vienna:

Drs. Julius Bauer, Richard Bauer, Bustin, Elias, Erlacher, Leopold Freund, Froschels, Glaessner, Glas, Gottlieb, Julius Hass, Walter Hausmann, Hammerschlag, Leo Hess, Oskar Hirsch, Hecht, Lieben, Emst Lowenstein, Marburg, Henrich Neumann, Moriz Oppenheim, Pappenheim, Paschkis, Ernst Pick, Pollak, Porges, Ranzi, August Reuss, Sauser, Schilder, Schueller, Schur, Gottwald Schwarz, Max Sgalitzer, Scheminzky, Sicher, Silberstein, Stern, Stransky, Robert Stein, Weninger, Willheim, Emil Zak, Walter Zweig. Dr. Bruecke, of Innsbruck, has also been dismissed.

Among the physicians :

Prof. Ferdinand Blumenthal, the German authority on cancer, who was living in Vienna, is in prison; Prof. Oskar Frankel, the gynæcologist and histologist, and Prof. Knoepfelmacher, the well-known specialist in children's diseases, have committed suicide.

It must be pointed out that these measures have been directed against men of varying political convictions, and have hit those who were active in the Christian movement and those who were simply opposed to official Nazi principles, as well as demo. crats, socialists and Jews.

Margaret Gardiner. 23 Haymarket, London, S.W.1. June 3.

\section{Darwin Misunderstood}

To argue fully Sir Edward Poulton's two main points 1 against my biography-the "fragmeniary" nature of Darwin and his "fear" of his father-would take more space than I can ask for. I will only remark on the first point that the term "fragmentary" was intended by me to refer primarily to categories of imaginative and intellectual activity, and that my case is not even touched by the fact that Darwin was, as everyone knows, the best of neighbours and friends; and on the second point that no more is
Darwin's alleged "fear" of Robert Darwin disproved by citing his "boundless and most touching reverence," since-as any psychologist might testify-it is the very "boundlessness" of that reverence which suggests some hidden and contradictory motivation, lying in all probability, I would hazard, below the threshold even of Charles Darwin's own consciousness.

I stand by both these points (though admitting that the second can be of its nature only speculative), but $I$ will readily confess that in relation to the first some of my statements were either too bold or too bald-sometimes both-and have been amended in the American edition published last month by the Yale University Press, where the sub-title "The Fragmentary Man" has been retired from the titlepage to its proper place-the final chapter which I myself would prefer to regard as a personal comment upon, rather than integral part of, my biography. To make my point of view-which is one of the highest admiration for Darwin as man and as scientistrather clearer, I should like to quote a few lines which appear in my American but not English preface to the book: "If I would attack anything, it is neither Darwin nor even Darwinism but dogmatism, above all that dogmatism which regards its own particular truth-whether scientific, artistic, or religious-as final. Like Emerson, I do not believe in final truths, nor do I regard it as a derogation of a great man to indicate that he, like every other natural creature, had his limitations. On the contrary, I would contend that greatness only yields its full harvest when its limitation is completely understood."

I should also like to stress the fact that my book is primarily a biography - in nineteen, indeed, out of twenty chapters - and not only of Charles Darwin but also of his grandfather Erasmus, and of the immediate Darwin and Wedgwood families from 1730 to 1896 .

GEOFFREY WEST.

22 Lathbury Road, Oxford.

${ }^{1}$ NATUR, 141, 807 (May 7, 1938).

Those who have read the words quoted from $\mathrm{Mr}$. Geoffrey West's book will have formed their own opinions upon the fairness of my comments. I feel sure that they will be glad to learn the intentions of the author and also to know that the word "fragmentary" is not prominent in the American edition.

\section{Wykeham House, Oxford.} Edward B. Poulton.

\section{Convergent Sunbeams}

I CAN add to the correspondence on the above subject in NATURE of February 19 and March 26 by reporting that $I$ have observed the phenomenon on numerous occasions at Diyatalawa, a village at an altitude of $4,000 \mathrm{ft}$. on the eastern side of the central hills of Ceylon. The western horizon about eight miles away is the edge of a block of rough mountainous country with many peaks of about 7,000 ft. altitude (including the well-known Adam's Peak). During the clear weather of spring and summer, I frequently observed the shadows converging on the eastern horizon at sunset, and I used to wonder if they could be produced by prominent peaks as well as by clouds.

J. E. JACKson.

Survey Office,

Badulla, Ceylon.

April 24. 